$$
\begin{array}{r}
\text { UDK: } 94(497.6 \text { Š. Brijeg)“1945/1948“ } \\
\text { Prethodno priopćenje } \\
\text { Primljen 15. V. 2020. }
\end{array}
$$

HRVOJE MANDić

Središnji ured za arhivsku građu Sveučilišta u Zagrebu

hmandic@unizg.hr

\title{
KAZNENE EKSPEDICIJE KOMUNISTIČKIH VLASTI PROTIV ŠIROKOBRIJEŠKE PROTUKOMUNISTIČKE GERILE 1945. - 1948. GODINE
}

\section{Sažetak}

Protukomunističke gerile su naoružane skupine koje su se u poratnome razdoblju suprotstavljale novouspostavljenomu komunističkom režimu. Širokobriješka protukomunistička gerila bila je jedna od najbrojnijih u zapadnoj Hercegovini poslije Drugoga svjetskog rata, a vojno i politički organizirali su se u lipnju 1946. te utemeljili Prvi hercegovački ustaško-križarski zdrug pod zapovjedništvom ustaškoga satnika Bože Mandića. Politički cilj protukomunističke gerile bio je rušenje komunizma zbog zločina koje su partizani počinili nad Hrvatima i drugim narodima pred kraj Drugoga svjetskog rata i nakon njegova završetka. Komunistička partija Jugoslavije (KPJ) označila je navedenu gerilu kao prijetnju za proces uspostave vlasti. Pomoću represivnoga aparata KPJ organizirala je niz kaznenih ekspedicija s ciljem likvidiranja istih na prostoru zapadne Hercegovine. Protukomunistička gerila je $u$ poraću, $u$ borbi za život, u uvjetima stalnih sumnjičenja, izdaja i pogibija od strane tajne policije KPJ, počinila zločine najčešće prema narodnim odbornicima, njihovim obiteljima i članovima Saveza komunističke omladine Jugoslavije (SKOJ). Agenti UDBA-e u početku nisu imali uspjeha u likvidaciji protukomunističke gerile te je KPJ utemeljenjem dobrovoljačke milicije i angažiranja uhoda po selima organizirala niz kaznenih ekspedicija $u$ kojima su agenti UDBA-e od 1946. do 1948. pobili većinu širokobriješke 
protukomunističke gerile. Preostale uhvaćene širokobriješke gerile osudili su na smrt strijeljanjem ili na višegodišnju robiju.

Ključne riječi: Široki Brijeg; protukomunistička gerila; Božo Mandić; Benedikt Benko Penavić; Vinko Škrobo; UDBA; KNOJ

\section{Uvod}

Protukomunističku gerilu, u narodu poznatu kao škripari ili križari, najčešće su činili pripadnici poraženih oružanih snaga NDH koji su se odbili predati komunističkim vlastima u poraću. Pripadnici ove gerile u Hercegovini, zbog kaznenih ekspedicija tajne policije KPJ, sve su teže mogli opstajati u blizini svojih kuća, pa su se skrivali u planinskim područjima Vrana, Ljubuše i Čvrsnice.

Prema istraživanjima povjesničara Ivice Lučića, nakon što su partizani zauzeli Hercegovinu, oko 800 ljudi povuklo se u šume. „Nakon amnestija 1945. i 1946. veći se broj predao, dok je oko 87 osoba, uglavnom pripadnika poraženih oružanih snaga NDH, ostalo u šumama raspoređeno u 13 grupa. Protukomunistička gerila se vojno i politički organizirala i prozvala križarima."

Fra Dominik Mandić je u svome referatu Križari - borci protiv Tita u Hrvatskoj iz 1946. istaknuo kako postoji bitna razlika između starih i novih križara u Hrvatskoj. Stari križari bili su odgojna organizacija katoličke mladeži i grana Katoličke akcije. Mandić navodi kako su novi križari vojnici koji su se borili u svojoj domovini s puškom u ruci protiv nasilničkoga režima maršala Josipa Broza Tita. Nadalje, ističe kako jedni s drugima nemaju nikakve genetičke i organizatorske veze, ali imaju zajednički naziv i opće kršćanske ideale. „Noviji križari, a riječ je o hrvatskim protukomunističkim snagama koje se bore protiv komunista ateista, nastavili su borbu protiv Titova režima i njegove vojske nakon zauzimanja cijele Jugoslavije." U nastavku referata Mandić navodi kako su križari spontano i u početku, bez ikakvih međusobnih veza, nastajali kao razasute borbene grupe po šumama i planinama, sastavljene od

IviCA LuČIć, „Hrvatska protukomunistička gerila u Bosni i Hercegovini od 1945. do 1951.“, Časopis za suvremenu povijest, Zagreb, god. XLII. (2010), br. 3., str. 650. 
nerazoružanih hrvatskih vojnika i ljudi koji su u opasnosti za život i u opasnosti od novoga režima postali borci protiv komunizma. „Borbene grupe su u početku bile sastavljene od raznih imena dok nisu uzeli ime križari što označava vjerski karakter borbe protiv bezbožnog komunizma. Na svoje hrvatske zastave stavili su veliki križ. Poruka njihove političke borbe prenošena je geslom 'Za Hrvatsku i Krista - protiv komunista' što znači da su se borili protiv komunista, a za vjeru i samostalnu Hrvatsku." ${ }^{2}$

U navedenome izvješću fra Dominik Mandić ističe kako je među pripadnicima protukomunističke gerile dosta pripadnika stare križarske organizacije. Zaključuje kako komunisti drže da su pripadnici stare križarske organizacije i novi križari, koji se bore oružjem protiv komunističke vlasti, zapravo jedna te ista organizacija. ${ }^{3}$ Nije skrivao simpatiju prema širokobriješkim križarima. Razlog je za to obiteljski, ponajprije jer su Mariofil Mandić i fra Dominik Mandić bili rođaci.

Jugoslavenski komunisti nazivali su ih još i odmetnicima, banditima, kamišarima, šumnjacima, a u Hercegovini najčešće škriparima. Komunističke vlasti amnestijom su pozivale sve one koji su se od nje odmetnuli, a nisu počinili zločine na povratku kućama, uz jamstvo da ih neće kazneno goniti. ${ }^{4}$ Prema dostupnim podatcima, oko 150 širokobrijeških pripadnika protukomunističke gerile odbilo je amnestiju od kolovoza

2 Amir OBнOĐAš I DR., Ustaška vojnica 2; Oružana sila Ustaškog pokreta u Nezavisnoj Državi Hrvatskoj 1941.-1945. (druga knjiga, rujan 1943. - svibanj 1945.), Despot Infinitus d.o.o., Zagreb, 2013., str. 250. Usp. ZDENKO RADELIĆ, Križari: gerila u Hrvatskoj 1945. - 1950., Dom i svijet, Zagreb, 2011., str. 91 i 102.

3 Usp. Bosna i Hercegovina (dalje: BiH) - Arhiv župe i samostana Uznesenja Blažene Djevice Marije Široki Brijeg, dalje: (AŽSUBDMŠB) - Mandićeva ostavština, sv. 3, mapa 1, f. 74. Usp. ZDENKO RADELIĆ, „Projugoslavenska protukomunistička gerila u Hrvatskoj nakon Drugog svjetskog rata", Časopis za suvremenu povijest, Zagreb, god. XXXV. (2003.), br. 2., str. 466.; Z. RAdelić, Križari..., str. $380 .-413$.

4 Usp. I. LuČIĆ, $n$. dj., str. 635. 
1945. jer je zapovjednik Božo Mandićs to izričito zabranio. ${ }^{6}$ Povjesničar Lučić smatra kako se malomu broju njih sudilo, a i kada se sudilo, često su to bili montirani sudski procesi. „Škripari su u poraću, u očajničkoj borbi za život, u uvjetima stalnih sumnjičenja, izdaja i pogibija od strane tajne policije KPJ počinili zločine najčešće prema narodnim odbornicima, njihovim obiteljima i članovima Saveza komunističke omladine Jugoslavije (SKOJ)."7

\section{Utemeljenje Prvoga hercegovačkog križarskog zdruga - kralj Tomislav}

Na području Širokoga Brijega protukomunistička gerila organizirala se i utemeljila 27. lipnja 1946. Prvi hercegovački ustaški križarski zdrug - I. hrvatsku diviziju kralj Tomislav na čelu sa satnikom Božom Mandićem iz Širokoga Brijega. Božo Mandić i Marko Lončar sazvali su sastanak svih pripadnika protukomunističke gerile na području zapadne Hercegovine 27. lipnja kod Šantića Lokve u Dabilu (selo Crnač). Prema iskazu zarobljenoga pripadnika protukomunističke gerile Ivana Lasića hranu su im donosili jataci Pero Zeljko Tokalić i oko njega 2-3 kuće Zeljka Tokalića iz Crnča. ${ }^{8} \mathrm{Na}$ tome sastanku bili su prisutni svi, osim skupine pod vodstvom Nike Vladićeve. ${ }^{9}$ Božo Mandić započeo je sastanak govorom u kojem je istaknuo kako je nemoguće boriti se protiv vlasti bez vojne

5 Božo Mandić odbio se predati kod Bleiburga i vratio se u Hercegovinu s određenim političkim ciljevima i ambicijama. Vidi: HrvoJE MANDIĆ, „Izbačeni učenici širokobriješke gimnazije od 1941. do 1944. godine“, Zbornik radova s međunarodnoga znanstveno-stručnog skupa u povodu 10o. obljetnice Franjevačke klasične gimnazije s pravom javnosti na Širokom Brijegu, Ivan ŠEvo (gl. ur.), Hercegovačka franjevačka provincija BDM, Široki Brijeg - Mostar, 2019., str. 218. - 219.

$6 \quad$ Škripar Ivan Pavković u iskazu na upit zašto nije prihvatio amnestiju KPJ od 5. kolovoza 1945. navodi: „... svim škriparima njih 150, Bože Mandić rekao da svaki čovjek koji je vršio bilo kakvu funkciju u ustaškom aparatu ne smije prihvatiti amnestiju“. Republika Hrvatska (dalje: HR) Hrvatski državni arhiv (dalje: HDA ) - 2088, Križarske grupe zapadne Hercegovine 1945. - 1948. (dalje: KGZH 1945. - 1948.), Iskaz Ivana Pavkovića od 13. ožujka 1948. u Odjeljenju UDB-e u Mostaru, 1.3., str. 2.

$7 \quad$ I. LuČIĆ, $n$. dj., str. $637 .-638$.

8 Usp. HR - HDA - 2088 - KGZH 1945. - 1948., Iskaz Ivana Lasića od 1. ožujka 1947. u Odjeljenju UDB-e u Mostaru, 1.2., str. 5.

$9 \quad$ Usp. isto, str. $5 .-6$. 
organizacije. Rekao je kako trebaju stvoriti jedno zapovjedništvo koje bi bilo podijeljeno u postrojbe. Zapovjedništvo bi izdavalo naređenja i ostale upute za djelovanje pripadnicima protukomunističke gerile. Nadalje, predložio je naziv ustaško-križarski zdrug i mogućnost glasanja za izbor zapovjednika. Benedikt Benko Penavić, istaknuti križar i odani Mandićev prijatelj, istakao je kako trebaju izabrati Božu Mandića zbog toga što je najškolovaniji i najstariji ustaški časnik. ${ }^{10}$ Mandić je uzeo riječ i rekao da se zdrug dijeli u bojne, a bojne u satnije. ${ }^{11}$ Navedeni zdrug početkom srpnja 1946. sastojao se od četiri bojne koje su brojile 42 križara, najviše iz Širokoga Brijega. Od poznatijih pripadnika protukomunističke gerile u zdrugu su djelovali Božo Mandić, Benedikt Benko Penavić, Vinko Škrobo, Jozo Vidović Busovača i Mariofil Mandić. ${ }^{12}$

Prema zapovijedi Prvoga hercegovačkog ustaško-križarskog zdruga zapovjednik Božo Mandić imenovao je ustaškoga poručnika Niku Vladića zapovjednikom I. bojne, za zapovjednika II. bojne imenovan je poručnik Marko Lončar, za zapovjednika III. bojne poručnik Benedikt Benko Penavić i za zapovjednika IV. bojne poručnik Stipica Brekalo. Za zapovjednika 5. satnije II. bojne imenovan je ustaški zastavnik Drago Ćorić, za zapovjednika 9. satnije III. bojne Mirko Lončar Ivišić, za zapovjednika 10. satnije III. bojne Mariofil Mandić i za zapovjednika 6. satnije II. bojne Lovro Bošnjak. Prema naredbi ustaškoga zapovjednika Bože Mandića svi imenovani časnici morali su stupiti u dužnost i prišiti činove. Nadalje, u I. bojnu zapovjednik Mandić dodijelio je sljedeće pripadnike zdruga: Stojana Zovku, Vinka Škrobu, Marka Glavanića,

10 Benko Penavić je završio peti razred u školskoj 1941./1942. godini, kada je izbačen iz širokobriješke gimnazije jer se isticao među kolegama kao nacionalist. Zahvaljujući njegovu profesoru fra Radoslavu Glavašu, završio je Drugu gimnaziju u Zagrebu. Kao gimnazijalac u Zagrebu bavio se politikom. Priključio se oružanim snagama NDH i sudjelovao u borbama protiv partizana u Širokome Brijegu od studenoga 1944. do veljače 1945., kada se povukao s oružanim snagama NDH i hrvatskim civilima prema Austriji. Nakon povratka s križnoga puta kratko je služio Jugoslavensku armiju (JA) i dezertirao. Usp. H. MANDIĆ, „Izbačeni učenici...", str. 227.

${ }^{11} \quad$ HR - HDA - 2088 - KGZH 1945. - 1948., Iskaz Ivana Lasića od 1. ožujka 1947. u Odjeljenju UDB-e u Mostaru, 1.2., str. 6.

${ }_{12}$ Republika Hrvatska (dalje: HR) - Hrvatski državni arhiv, Zagreb (dalje: HDA) - D2371 Zbirka mikrofilmova Ministarstvo oružanih snaga 53-b, rola br. 251. (dalje: ZM-MINORSMF-D-2371, rola br. 251.), snimak 412. 
Iliju Ćorića, Ilinu Kozinu, Stanka Cvitkovića, Ivana Vesića, Peru Kvesića, Kristu Markovskog, Andriju Jurića, Ivicu Bebeka, Osmana Gubelića, Stanka Arapovića i Zdravka Primorca. Ukupno 14 križara. U II. bojnu dodijelio je sljedeće pripadnike zdruga: Marka Lončara (zastavnik), Iliju Ljubića, Stipu Karačića, Božu Hrkaća, Stanka Ćavara, Karla Božića, Antu Marića, Božu Ćavara i Luku Vrljića. U šestu satniju dodijelio je: Lovru Bošnjaka, Božu Bošnjaka, Ivana Lasića, Veseljka Rezića, Juru Zovku, Zlatka Ćavara i Juru Šarića. Ukupno 16 križara. U III. bojnu zapovjednik Božo Mandić dodijelio je sljedeće pripadnike zdruga: Deveta satnija u sastavu: Marko Lončar (zastavnik), Vidak Prskalo, Stanko Slišković, Jozo Vidović, Stanko Zeljko i Ante Bosić. Deseta satnija: Marijofil Mandić (zastavnik), Marko Čobalo, Mile Bošnjak, Jakov Alpeza, Neđo Jakovljević i Šimun Ćorić. Ukupno 12 križara. U dokumentu je izostavljen popis križara IV. bojne. ${ }^{13}$

Božo Mandić u zapovijedi koju je uputio pripadnicima zdruga u lipnju 1946. navodi:

Primijetio sam kako pojedini pripadnici ovog zdruga kreću kojekuda bez ičijeg znanja. Radi veće sigurnosti pojedinca kao i cjelini zabranjujem kretanje bez razlike, bez odobrenja pretpostavljenog. Primijetio sam kako pojedinci psuju i govore među sobom i drugima svakakve riječi. To nije dostojno uopće čovjeku, a naročito vjerskom i nacionalnom vojniku. Psovka i druge pogrdne riječi zrcalo su svakog pojedinca kao cjeline. Međusobno bratstvo među nama ne dolazi do izražaja. Pojedini podcjenjuju svoje kolege, možda što su mladi ili što su kasnije stupili u zdrug. Radi toga moramo svim silama raditi na produbljivanju bratstva i sve svoje sile moramo upotrijebiti na dobroj zajednici i pokretu. ${ }^{14}$

Uveo je čitav niz vojničkih pravila koja se tiču održavanja naoružanja, čuvanja straže, opskrbe, sustava kažnjavanja, sustava nadzorne službe među križarima kao i zajedničke molitve koju čita nadzorni časnik svakoga dana. Uvedena je funkcija nadzornoga časnika koji je, između ostaloga, u zdrugu morao odrediti mjesto spavanja za pripadnike

Usp. HR - HDA - D2371 - Zbirka mikrofilmova MINORS 53-b, snimak 412.

14 Isto, snimak 413. 
križarskih bojni. Svaka bojna imala je svoga nadzornog časnika koji se mijenjao svaka 24 sata.

\begin{abstract}
Zabranjuje se izviđanje po kotama. Ukoliko će netko pjevati neka ne pjeva glasno. Opaženo je kako pojedinci prilikom dosadašnjih borbi sa partizanima izvlače se bez naloga i ne gledajući na druge. Zabranjuje se od danas strogo da se i jedan pripadnik izvlači bez naloga. Napominje se svakom pripadniku neka puca na onoga koji počne bježati bez dane zapovijedi. Svaki strojničar ima pravo pucati na svakog pomoćnika ukoliko on počne bježati bez naloga. ${ }^{15}$
\end{abstract}

Prema nekim podatcima bilo je ukupno 150 pripadnika protukomunističke gerile u navedenome zdrugu 1946. godine. ${ }^{16}$ Glavni operativac križara bio je mladi i vrlo sposobni Benedikt Benko Penavić. ${ }^{17}$ Nameće se logičan zaključak kako su jedini ciljevi protukomunističke gerile, politički i vojno organizirane u Prvi hercegovački križarski zdrug - kralj Tomislav, bili isključivo opstati i ostati. U takvome sustavu vrijednosti činili su zločine u kojima su najčešće stradavali nedužni.

U jednoj od brojnih kaznenih ekspedicija pripadnici Ureda za državnu sigurnost (UDBA) i Korpusa narodne obrane Jugoslavije (KNOJ) zarobili su 15. srpnja 1946. Arhiv Prvoga hercegovačkog križarskog zdruga, ${ }^{18}$ koji je agentima UDBA-e omogućio uvid u identitet pripadnika širokobriješke protukomunističke gerile, njihova kodna imena, jatake po selima, tajno sporazumijevanje i štošta drugo. Upravo su na temelju tih podataka pripadnici UDBA-e razradili operacije likvidiranja istih.

\title{
2. Kaznene ekspedicije represivnoga aparata KPJ protiv širokobriješke protukomunističke gerile
}

Okružni komitet KPJ za Hercegovinu u dopisu od 22. travnja 1946., upućenu Sreskomu komitetu KPJ Široki Brijeg, ističe kako je prioritet

$15 \quad$ Isto, snimak 413. - 419 .

16 Usp. HR - HDA - 2088 - KGZH 1945. - 1948., Iskaz Ivana Pavkovića od 13. ožujka 1948. u Odjeljenju UDB-e u Mostaru, 1.3., str. 2.

${ }_{17}$ Usp. BiH - AŽSUBDMŠB - Mandićeva ostavština, svezak 3, mapa 2, f. 67.

18 Usp. HR - HDA - 2088 - KGZH 1945. - 1948., Radni materijal - natuknice i kronologija, izradio Šefko Pašić, 1.10., str. 2. 
Okružnoga komiteta KPJ za Hercegovinu uništenje protukomunističke gerile. U daljnjem tekstu dopisa navode kako je taj komitet angažirao 29. hercegovačku diviziju, KNOJ i Odjeljenje zaštite naroda i narodnosti (OZNA) za zajedničke kaznene ekspedicije uz suradnju partijskih organizacija na terenu i s ciljem uništenja istih. U dopisu kritiziraju partijsku organizaciju u srezu Široki Brijeg zbog nemara jer nije dala nikakvu podršku vojsci. U dopisu se ističe da partijske organizacije zajedno s vojskom moraju uništiti protukomunističku gerilu na svome sektoru, a da sreski komiteti moraju kontrolirati partijske organizacije i u punoj mjeri ih pomagati. „Narod treba angažovati i vaspitati u tom duhu - uništenja posljednjih ostataka bandi - fašističkih pomagača. Po ovom pitanju se vrlo malo učinilo (...) U Trebinju je jedna žena jatak rekla oficirima 'Vaše je da ih gonite a moje da im pomažem' nato su se komunisti na terenu smijali“. U daljnjem tekstu dopisa navodi se kako se presude sudova jatacima ne koriste i na tim primjerima "ne vaspitavaju ostali ukazujući na njih kao na narodne izdajnike“. Zatim ističu kako križari jatake često proglase narodnim mučenicima. „Naglašavamo da će Okružni komitet zbog neizvršenja zadataka pozivati pojedine sreske komitete na odgovornost $^{{ }^{\prime 19}}$. Iz okružnice je vidljivo kako postrojbe UDBA-e i KNOJ-a nisu bile dovoljne za obračun sa škriparima i pasivizaciju Hrvata u Hercegovini. Pripadnici protukomunističke gerile bili su sigurnosno najveći izazov novoj komunističkoj vlasti na prostoru zapadne Hercegovine.

Sreski komitet KPJ Široki Brijeg u dopisu od 6. kolovoza 1946., upućenu svim partijskim ćelijama na terenu sreza, navodi kako je na zajedničkome savjetovanju članova KPJ 30. srpnja utvrđeno da je partijska organizacija zakazala po pitanju uništenja bandi na terenu. U tome dopisu istaknuto je nekoliko zaključaka kojima se trebaju rukovoditi partijski dužnosnici kako bi se uništilo djelovanje protukomunističke gerile na širem području Širokoga Brijega. Prvi su zaključci s toga sastanka nužnost isticanja narodne vlasti mjesnomu pučanstvu te prokazivanje

19 Bosna i Hercegovina (dalje: BiH), Arhiv hercegovačko-neretvanske županije (dalje: AHNŽ), Sreski komitet saveza komunista Lištica (1945. - 1955.) (dalje: SKSKL), Sreski komitet KPJ Široki Brijeg 1946. - 1947., kut. 18., dopis Sreskom komitetu KPJ Široki Brijeg, br. 910/46. od 22. travnja 1946. Usp. I. LuČIĆ, $n$. dj., str. 651. 
neprijateljskoga rada i onih koji aktivno pomažu gerili u šumi. U skladu s tim navodi se kako narodu treba konkretno ukazivati koliko je protukomunistička gerila štetna za narod, od pljačkanja do ubojstva odbornika i vojnika. U drugome zaključku piše kako rukovodeće gerilce na terenu treba izolirati od jataka, kako bi mjesno pučanstvo jatake izopćilo iz zajednice i počelo napadati. Isto tako navodi se da kod neprijatelja treba stvarati strah i nesigurnost te da vojska ima zadatak vršiti ekonomsko kažnjavanje. Zatim, u zaključku se ističe kako članovi KPJ moraju biti u stalnome dodiru s vojskom kako ne bi došlo do druge krajnosti, do okretanja protiv naroda i oduzimanja od istoga naroda, što koristi neprijatelju. U trećem zaključku navedeno je kako treba poštivati osnivanje dobrovoljačke milicije i paziti da u miliciju ne uđu neprijatelji. „S postojećim milicajcima treba politički raditi, čitati razne članke iz Bor$b e$, često ih okupljati i davati im razne prijedloge što bi se moglo napraviti po pitanju bande, a u izvjesnim trenutcima održavati s njime zasjede itd. Kroz ovakav rad će te isprobati svakog pojedinca od kojih ćemo omasoviti našu partiju“. U zadnjoj, četvrtoj točki piše kako komunisti na terenu trebaju što bolje razviti obavještajnu službu koristeći svoju obitelj, bližu rodbinu i sve dobre simpatizere na terenu. Potonje treba pridobiti ako im se vješto pristupi. U zadnjoj točki predlaže se povezivanje partijskih rukovoditelja i vojnih postrojbi na terenu u sastanke na kojima treba razmijeniti informacije s ciljem uništenja škripara. ${ }^{20} \mathrm{KPJ}$ nije ništa prepuštala slučaju i s najviše razine izrađena je strategija obračunavanja s pripadnicima protukomunističke gerile. Bio je to totalni rat partije protiv ostataka poražene hrvatske vojske na prostoru zapadne Hercegovine.

KPJ je po hercegovačkim selima formirala dobrovoljačke milicije sastavljene od svojih članova, kandidata za prijam u Partiju i skojevaca. To su bili domaći ljudi koji nisu mogli zadržati povjerenje mjesnoga pučanstva u trenutku kada bi ubili nekoga od pripadnika hrvatske protukomunističke gerile. Taj čin ubojstva najčešće je izazvao mržnju mjesnoga

20 Usp. BIH - AHNŽ - SKSKL (1945. - 1955.), Sreski komitet KPJ Široki Brijeg 1946. - 1947., kut. 18., dopis Svim partijskim ćelijama na terenu Sreza Široki Brijeg, br. 178/46. od 6. kolovoza 1946. Usp. I. LuČıć, $n$. dj., str. 646. 
pučanstva prema njima, što je te mladiće natjeralo da budu odani sljedbenici KPJ. Prema mišljenju povjesničara Lučića „takvi su kasnije bez pogovora obavljali sve zadaće, budno motreći na neprijatelje KPJ, koja je na taj način dobivala odane agente u neprijateljskom kraju”21.

Pripadnici Jugoslavenske armije (JA) bili su nemilosrdni u kažnjavanju ustaških jataka. Širokobriješki komunisti Draga Šoljić i Blaž Bušić kritizirali su u siječnju 1946. Ludviga Zadru jer je „plakao za ustaškim jatacima kada ih je naša vojska ubila u Donjim Mamićima" ${ }^{22}$. U dopisu Sreskoga komiteta KPJ Široki Brijeg od 17. lipnja 1946., upućenu Okružnomu komitetu KPJ za Hercegovinu, navodi se kako pripadnici 11. hercegovačke brigade teroriziraju mjesno hrvatsko pučanstvo. U tome dopisu stoji da su navedeni pripadnici prilikom borbe s protukomunističkom gerilom u Donjem Gracu tukli pojedine seljake. Iste večeri je nekoga čovjeka u Grabovoj Dragi vojska izvela pred kuću i držala ga svezana do tri sata u noći. U selu Crnač vojska je preko Mjesnoga odbora naredila da im seljaci moraju davati janjce i drugu hranu. „Na ovakav postupak vojske narod zadobiva još veće nepovjerenje u vojsku. Na ove postupke od strane vojske ukazali smo Štabu 11. hercegovačke brigade ${ }^{{ }_{23}}$. Povjesničar Ivica Lučić smatra kako je borba KPJ protiv pripadnika širokobriješke gerile i jataka imala najmanje dva cilja: uništiti svaku opasnost po svoju vlast i po osobnu sigurnost članova Partije, a opasnost su predstavljale naoružane grupe i pojedinci na terenu.

Njihovo uništenje demonstriralo je snagu nove vlasti i osiguravalo političku stabilnost. S druge strane u hrvatskim krajevima u kojima Partija nije imala znatnija uporišta organiziranom prisilnom masovnom hajkom naroda na škripare događala se diferencijacija. Dotada prilično kompaktna masa dijelila se na one koji su ustrajavali u potpori protukomunističkoj gerili, te na taj način ostajali na starim političkim pozicijama, i one koji susudjelujući u akcijama protiv škripara prihvaćali novu vlast, pa su se radikalnim postupcima vezali za nju. ${ }^{24}$

${ }_{21} \quad$ I. LuČIĆ, $n$. $d j$., str. 645.

${ }_{22}$ Isto, str. 646.

${ }_{23}$ BiH -AHNŽ - SKSKL (1945. - 1955.), Sreski komitet KPJ Široki Brijeg 1946. - 1947., kut. 18., dopis Okružnom komitetu KPJ za Hercegovinu u Mostaru, br. 123/46. od 17. lipnja 1946.

${ }^{24} \quad$ I. LuČIĆ, $n$. $d j$., str. 647. 
Partijskim dužnosnicima bilo je itekako u cilju „omekšati” mase i privući ih u Partiju. Danilo Bilanović je uime Sreskoga komiteta KPJ Široki Brijeg uputio dopis 19. srpnja 1946. Okružnomu komitetu KPJ za Hercegovinu u Mostaru u kojem stoji da je Komitet u Širokome Brijegu dobio dopis od partijske organizacije 29. hercegovačke divizije po pitanju prostorija za smještaj vojničkih ustanova.

Nepravilno je da opatice (sestre) stanuju u jednoj zgradi s oficirima što ometa rad i život kako oficira tako i samih opatica. Ovakav rad i trvenje između Sreskog narodnooslobodilačkog odbora i vojske štetan je i može koristiti samo neprijatelju. (...) U zajednici sa partijskim rukovodiocem 11. hercegovačke brigade donesite zajedničku odluku od smještaju opatica. Ako nema drugih zgrada osim one u kojoj sada stanuju oficiri i sestre, i ako je dobra zgrada gdje stanuju druge sestre, a mogu se smjestiti zajedno, onda ih preselite. Ovo posljednje učinite ako nema drugog izlaza i ako politički ne bi izgubili u masama. ${ }^{25}$

Kako je vrijeme odmicalo, KPJ je uvodila sve nemilosrdnije metode uništenja pripadnika širokobriješke protukomunističke gerile. U izvješću Sreskoga komiteta KPJ Široki Brijeg od 24. siječnja 1947., koje je upućeno Okružnomu komitetu KPJ Široki Brijeg, piše da je povodom poduzetih mjera internacije zavladao strah kod naroda.

Povodom dizanja fratara s ovog terena kod naroda se pojavilo negodovanje i jedan mali broj ljudi odobrava djelovanje vlasti kao ispravno ali to ne govori javno. Sami fratri pri polasku nastojali su sa svojim držanjem izazvati veći revolt kod naroda po ovoj stvari. Kad je selio fratar iz Mamića, preko 200 ljudi i žena okupilo se oko njega plačući što odlazi. Ovakva slična stvar se zapazila i na drugim mjestima odakle su fratri polazili. Narod je ovu stvar shvatio, da je nastao progon vjere od strane komunista, a ovu stvar neprijatelj ilegalno propagirao. ${ }^{26}$

${ }_{25}$ BIH - AHNŽ - SKSKL (1945. - 1955.), Sreski komitet KPJ Široki Brijeg 1946. - 1947., kut. 18., dopis Okružnom komitetu KPJ za Hercegovinu u Mostaru, br. 168/46. od 19. srpnja 1946.

${ }_{26}$ BIH - AHNŽ - SKSKL (1945. - 1955.), Sreski komitet KPJ Široki Brijeg 1946. - 1947., kut. 18., dopis Okružnom komitetu KPJ za Hercegovinu u Mostaru, br. 24/47. od 24. siječnja 1947., str. 1. 
U daljnjem tekstu dopisa navodi se kako je mali broj prijavljenih pripadnika protukomunističke gerile i da je u siječnju ubijen jedan. Slabo se uspjelo u prijavljivanju istih, u siječnju je ubijen jedan pripadnik protukomunističke gerile, a petero ih se predalo. Zaključuju kako se nije prijavilo više križara na amnestiju jer su Vinko Škrobo, Božo Mandić i ostali okupili oko sebe sve pripadnike protukomunističke gerile. Nadalje, navodi da po selima nemaju odane ljude koji će im pomoći u hvatanju istih jer dobar dio naroda misli da su oni čuvari vjere i ako se oni predaju, nestat će vjere. Zatim se ističe da u Širokome Brijegu svaki dan iščekuju internaciju, ali i da se s prezirom gledaju poduzete mjere. „Kod obitelji Penavić, Zadro itd. zapažala se izrazita mržnja prema Narodnooslobodilačkom pokretu“ ${ }^{\text {"27}}$. Obustavljena je podjela hrane na čitavome terenu, osim na području Mjesnoga odbora Čerin. U Mjesnome odboru Crnač, odakle su se tri križara prijavila na amnestiju, povratit će se obitelji u mahalu iz koje su se isti prijavili, a ujedno će biti podijeljena i hrana.

Ove poduzete mjere donijele su korist $u$ tome, što je spriječena banda $u$ svome djelovanju i što je nastala djelomična demoralizacija neprijatelja, jer mi očekujemo, da će se prijaviti još jedan manji broj odmetnika. Ima jedan manji broj naših simpatizera, koji namjeravaju seliti iz ovoga kraja u Vojvodinu ili Slavoniju iz straha pred pripadnicima protukomunističke gerile. Mjere internacije će negativno djelovati na sadnju duhana kod seljaka. Mi ćemo dalje uporno raditi na prijavljivanju istih i to preko pojedinih ljudi, jer se to do sada pokazalo u praski korisnije, nego putem konferencija. ${ }^{28}$

\section{U dopisu zatim stoji:}

Povodom poduzetih mjera, a naročito interniranje obitelji Penavić zapaža se kod Nikole Zadre, narodnog poslanika, i Joze Čuljka, zamjenika na-

${ }_{27}$ BIH - AHNŽ - SKSKL (1945. - 1955.), Sreski komitet KPJ Široki Brijeg 1946. - 1947., kut. 18., dopis Okružnom komitetu KPJ za Hercegovinu u Mostaru, br. 24/47. od 24. siječnja 1947., str. 1.

${ }_{28}$ BIH - AHNŽ - SKSKL (1945. - 1955.),Sreski komitet KPJ Široki Brijeg 1946. - 1947., kut. 18., dopis Okružnom komitetu KPJ za Hercegovinu u Mostaru, br. 24/47. od 24. siječnja 1947., str. 1-2. 
rodnog poslanika, kolebljiv stav prema Partiji s obzirom da im se obraća narod, a naročito čaršija kao najuglednijim ljudima radi intervencije i isti padaju u ovome trenutku pod utjecaj pojedinaca i sami nepravilno reagiraju. Radi ovoga mi ćemo opširnije razgovarati sa Zadrom i Čuljkom i ubjeditiih $\mathrm{u}$ ispravnost poduzetih mjera. ${ }^{29}$

Takve metode po kojima su obitelji pripadnika protukomunističke gerile premještane, premlaćivane i uzimane kao taoci izazvale su niz reakcija vodstva Prvoga hercegovačkog ustaško-križarskog zdruga prema Sreskomu komitetu u Širokome Brijegu. Prilikom likvidacije istih u zapadnoj Hercegovini glavni i odgovorni rukovoditelji komunističke tajne policije UDBA-e i KNOJ-a bili su Teufik Selimović Buđoni iz Tuzle i Mirko Praljak kao predsjednik Prijekoga suda i šef Opunomoćstva OZNA-e za Hercegovinu u Posušju 1947. godine. Praljak je kasnije došao u sukob s nekim rukovoditeljima i premješten je u Mostar u UDBA-u na niski položaj. Prema istraživanjima povjesničarke Blanke Matković jedan od načelnika OZNA-e bio je Teufik Selimović Buđoni, brat književnika Meše Selimovića. Obnašao je dužnost u vrijeme poraća kao pomoćnik ministra za unutarnje poslove Narodne Republike $\mathrm{BiH}$. Prozvan je nadimkom Buđoni zbog tjelesne sličnosti sa sovjetskim maršalom Semjonom M. Buđonijem. Prema izjavi Ismeta Serdarevića, zatočenika s Gologa otoka, Buđoni je bio prosrpski orijentiran, a od Aleksandra Rankovića dobio je sat s posvetom za posebne zasluge. Mirko Praljak bio je podređeni Buđoniju 1947. u Posušju. ${ }^{30}$ U Širokome Brijegu visokopozicionirani oficir UDBA-e bio je Marko Šoljić. ${ }^{31}$ Niži oficiri bili su Lovro Kovačević, major UDBA-e, rodom iz Makarske, gdje je kasnije bio na dužnosti predsjednika općine, a dok je bio u UDBA-i, obnašao je

29 BIH - AHNŽ - SKSKL (1945. - 1955.),Sreski komitet KPJ Široki Brijeg 1946. - 1947., kut. 18., dopis Okružnom komitetu KPJ za Hercegovinu u Mostaru, br. 24/47. od 24. siječnja 1947., str. 2.

3o Usp. Blanka Matković, „Poslijeratni komunistički zločini i grobišta u istočnoj Hercegovini“, Hum, časopis Filozofskog fakulteta Sveučilišta u Mostaru, Mostar, br. 9., (2012.) str. 200.

${ }_{31}$ Usp. Marko Šoljić bio je član Oblasnog komiteta KPJ za Zapadnu Hercegovinu. HrvoJE MANDIĆ, „Borbe za Široki Brijeg od početka studenog 1944. do. 7. veljače 1945., Polemos: časopis za za interdisciplinarna istraživanja rata i mira, Zagreb, god. XVI. (2013.), br. 32. str. 18. 
ulogu glavnoga odgovornog za likvidacije hrvatske protukomunističke gerile u Hercegovini. Nadalje, tu su bili i Mirko Despot, viši oficir iz Makarske koji se nije slagao s mostarskim utjecajima u UDBA-i i odstupio je s dužnosti, Ante Primorac iz Ljubuškoga, oficir UDBA-e, Neđo Ljepava, sekretar UDBA-e u Lištici (današnji Široki Brijeg) koji je činio čuda, a kasnije je prebačen u Foču pa u Novu Goricu gdje je obavljao dužnost carinika na granici prema Italiji. Poslije je završio kao skitnica u Mostaru. Uz navedene pripadnike UDBA-e još su bili i Himlija Cisić i Duka Pudar, Srbin iz Čapljine koji je kasnije postao glavni sudac Okružnoga suda u Mostaru. Pudar je osudio na smrt mnogo Hrvata iz zapadne Hercegovine, a naposljetku je otpušten iz svih dužnosti i radio je kao tajnik u Boksitnim rudnicima u Mostaru. Vasa Masalo je poslije likvidacije pripadnika hrvatske protukomunističke gerile prebačen u Kopar za šefa UDBA-e, a kasnije je u Zagrebu u zračnoj luci bio šef za putovnice. Nadalje, Krešo Primorac, šef UDBA-e za Lišticu, i Vice Sopta, jedini pripadnik UDBA-e iz Širokoga Brijega, bili su angažirani za progon pripadnika protukomunističke gerile. ${ }^{32}$

\section{Otvoreni rat širokobriješke protukomunističke gerile protiv KPJ i njezine mreže doušnika}

Na meti širokobriješke protukomunističke gerile bio je visokopozicionirani komunist i oficir UDBA-e Marko Šoljić. Protukomunistički gerilci Benko Penavić i Mariofil Mandić zajedno su sastavili prijeteće pismo, potpisali ga i uputili 6. svibnja 1946. Marku Šoljiću. U pismu ga prozivaju jer je organizator zločina nad križarima i jatacima. „Svojom ćeš glavom ti, Šolje, platiti za svaki zločin koji bude od danas učinjen nad našim narodom". U pismu mu nude mogućnost pregovora i poručuju mu da mora prestati s organiziranjem kaznenih ekspedicija protiv njih i jataka ili će platiti glavom kao i njegova obitelj. ${ }^{33}$ Još mu je oštrije pismo uputio zapovjednik ustaško-križarskoga zdruga, satnik Božo

Usp. BiH - AŽSUBDMŠB - Mandićeva ostavština, sv. 10, mapa 1, podmapa 5., f. 66.

33 Usp. HR - HDA - 2088 - KGZH 1945. - 1948., Pismo Mandića i Penavića upućeno 6. svibnja 1946. Marku Šoljiću, 2.2., str. 1. 
Mandić 21. svibnja 1946. U pismu navodi kako je došao kraj njegova opstanka: „Sad u ovom bijesu ne znajući što ćete drugo napraviti pokupili ste naše obitelji kao taoce (...) Udarite na nas svim mogućim sredstvima, a i mi ćemo na Vas pa šta kome da Bog i sreća junačka. Ne možete nam ništa koji smo pod oružjem pa onda možete iskaljivati svoj bijes nad nezaštićenom golorukom djecom i ženama“. Mandić zatim ističe:

... ako ne pustite naše obitelji u roku od 48 sati mi se nećemo obazirati ni našto, nego će krv proteći potocima i rijekama. Na području zapadne Hercegovine, u selima i mjestima, neće više postojati narodna vlast. Svi pojedinci, odbornici, bit će pobijeni kao i njihove obitelji. Svi oni koji se nalaze u Komunističkoj partiji, Savezu komunističke omladine Jugoslavije, Narodnooslobodilačkom frontu i ostalim vašim organizacijama i njihove obitelji, obitelji svih onih koji se nalaze u vojsci i miliciji. Shvatite ovo najozbiljnije i najažurnije. ${ }^{34}$

Prema dostupnim arhivskim izvorima pripadnici Prvoga hercegovačkog ustaško-križarskog zdruga započeli su kaznene ekspedicije protiv komunističke vlasti na širem području Širokoga Brijega. Tako je zapovjednik Božo Mandić naredio ubojstvo Mile Vuletić, zastavnice JA. Ubio ju je Benko Penavić 23. lipnja 1946. u Dobrkovićima. ${ }^{35}$ U Borajni su 27. srpnja 1946. škripari Vinko Škrobo i Mariofil Mandić ubili seljaka Milu Šimića. Sutradan su u Medovićima objesili Matu Alpezu i njegovu suprugu Katu. ${ }^{36}$ Navodno je Ivan Lasić 12. srpnja 1946. ubio jednoga vojnika JA u Gornjem Gracu. ${ }^{37}$ Zatim, u Crnču su 16. prosinca 1946. pod vodstvom Vinka Škrobe pripadnici protukomunističke gerile ubili Blagu Zeljku i njegovu suprugu. Isti su sutradan, 17. prosinca, ubili demobiliziranoga vojnika u Uzarićima. ${ }^{8} \mathrm{U}$ Mokrome su pripadnici

${ }_{34}$ HR - HDA - 2088 - KGZH 1945. - 1948., Pismo Bože Mandića upućeno 21. svibnja 1946. Marku Šoljiću, 2.3., str. 1.

35 Usp. HR - HDA - 2088 - KGZH 1945. - 1948., Radni materijal - natuknice i kronologija, izradio Šefko Pašić, 1.10., str. 4. Usp. HR - HDA - 2088, Križarske grupe zapadne Hercegovine 1945.-1948., Iskaz Stanka Ćavara od 15. ožujka 1948. u Odjeljenju UDB-e u Mostaru, 1.6., str. 3.

${ }_{36}$ Usp. HR - HDA - 2088 - KGZH 1945. - 1948., Radni materijal - natuknice i kronologija, izradio Šefko Pašić, 1.10., str. 4.

37 Usp. isto, str. 4.

${ }_{38}$ Usp. isto, str. 6. 
protukomunističke gerile Stanko Slišković, Jozo Musa, Stanko Karačić, Vinko Škrobo i drugi 18. prosinca 1946. ubili dvojicu omladinaca. ${ }^{39}$ Iste godine ubili su Stipu Leku i njegovu suprugu Dragicu. Benko Penavić ubio je odbornika Ivana Svrzu 1946. u Knešpolju. Vinko Škrobo ubio je jedan bračni par u Dobrkovićima. V. Škrobo i Niko Vladić su u Krivodolu ubili jednoga odbornika. ${ }^{40}$ Skupina pripadnika protukomunističke gerile pod vodstvom Vinka Škrobe je u selu Dužicama 17. ožujka 1947. ubila jednoga omladinca, a par dana kasnije u selu Ledincu ubili su još jednoga. ${ }^{41}$ U selu Rakitnu 14. travnja 1947. Stipe Brekalo Nević opljačkao je kuću Stojana Tokića. U Borajnoj je 11. svibnja 1947. V. Škrobo ubio Matišu Mikulića. U njegovoj skupini još su bili Jozo Brekalo, Jago i Vinko Pavković te Petar Ljubić Čutić. ${ }^{42}$ U Dobrkovićima su 30. lipnja 1947. Vinko Škrobo i Tomo Mandić likvidirali vojnika KNOJ-a. Nekoliko dana kasnije, točnije 1. srpnja, Vinko Škrobo objesio je dva seljaka u Gorancima. ${ }^{43} \mathrm{U}$ istome selu Jozo Vidović Busovača objesio je 5. kolovoza 1947. seljake Džidića i Stojkovića. ${ }^{44}$ U Gorancima su 8. kolovoza 1947. Vinko Škrobo, Jozo Vidović Busovača, Slavko Naletilić, Marijan Naletilić, Tomo Mandić, Jozo i Vinko Pavković objesili jednoga mladića, a drugoga su ubili iz vatrenoga oružja. ${ }^{45}$ U Crnim Lokvama Benko Penavić je 18. kolovoza 1947. ubio Matiju Galića. ${ }^{46} \mathrm{U}$ Dabilu je desetak pripadnika protukomunističke gerile pod vodstvom B. Penavića 31. kolovoza 1947. napalo pripadnike JA. U okršaju je ubijen jedan vojnik, a dvojica su ranjena. ${ }^{47} \mathrm{U}$ Tribistovu su pripadnici protukomunističke gerile 14. rujna 1947. pod vodstvom Joze Brekala objesili dva seljaka. Četiri dana kasnije

${ }_{39}$ Usp. isto, str. 6. Usp. HR - HDA - 2088 - KGZH 1945. - 1948., Iskaz Ivana Lasića od 1. ožujka 1947. u Odjeljenju UDB-e u Mostaru, 1.2., str. 3.

40 $\quad$ HR - HDA - 2088 - KGZH 1945. - 1948.,Radni materijal - natuknice i kronologija, izradio Šefko Pašić, 1.10., str. 6. Usp. HR - HDA - 2088 - KGZH 1945. - 1948., Iskaz Ivana Lasića od 1. ožujka 1947. u Odjeljenju UDB-e u Mostaru, 1.2., str. 4.

${ }^{41}$ HR - HDA - 2088 - KGZH 1945.-1948., Radni materijal - natuknice i kronologija, izradio Šefko Pašić, 1.10., str. 10.

42 Usp. isto.

43 Usp. isto.

44 Usp. isto.

45 Usp. isto, str. 11.

${ }_{46}$ Usp. isto.

47 Usp. isto. 
križari Stipe Brekalo, Vinko Pavković, Slavko Naletilić, Stanko Ćavar, Bože Mandić i Božo Ćavar objesili su u Rakitskome gvozdu Franju Rezu. ${ }^{48}$ Isti dan je druga skupina u Kolobarića Docu opljačkala Franju Martinovića. Skupina pripadnika protukomunističke gerile pod vodstvom Vinka Škrobe 21. listopada 1947. ubila je jednoga seljaka u Rujnu i ubacila ga u jamu. ${ }^{49} \mathrm{Na}$ području Širokog Brijega isti su ubili Peru Mikulića, Božu Brekala, Ivana Galića, Andriju Zovko, Andriju Češkića i Juru Čolaka. Zatim, pripadnici protukomunističke gerile ubili su i 18 vojnika JA i dva oficira KNOJ-a, ranili 12 vojnika JA i tri oficira KNOJ-a. Opljačkali su 35 domaćinstava. ${ }^{50}$

Kada se bolje pogleda ovaj pregled počinjenih ubojstava, uočljivo je da su pripadnici protukomunističke gerile počinili niz ubojstava od kraja rujna do prosinca 1946. i od veljače 1947. pa do daljnjega. Smatram da su nakon UDBA-ina ubojstva skupine pod vodstvom Mariofila Mandića na Mosoru 18. rujna pripadnici protukomunističke gerile pojačali napade na KPJ i na njihovu mrežu doušnika. Nakon ubojstva zapovjednika Bože Mandića krajem siječnja 1947. na planini Čvrsnici uslijedio je slom Prvoga hercegovačkog ustaško-križarskog zdruga. Preostali preživjeli pripadnici protukomunističke gerile djelovali su neorganizirano i najveći dio ubojstava počinili su od veljače do prosinca 1947. kako bi osvetili zapovjednika Božu Mandića.

\section{Ubojstvo pripadnika protukomunističke gerile pod vodstvom Mariofila Mandića na brdu Mosor}

Pripadnici Prvoga hercegovačkog ustaško-križarskog zdruga pod vodstvom zapovjednika Bože Mandića bili su svjesni da je slabio utjecaj UDBA-e na stanovništvo zapadne Hercegovine i svaki pokušaj aktivizacije pojedinih osoba na terenu od strane komunističkih vlasti pripadnici protukomunističke gerile su osujetili i pobili suradnike UDBA-e. UDBA

${ }_{48}$ Usp. isto, str. 12. Usp. HR - HDA - 2088 - KGZH 1945. - 1948., Iskaz Slavka Naletilića od 13. ožujka 1948. u Odjeljenju UDB-e u Mostaru, 1.4., str. 3.

49 HR - HDA - 2088 - KGZH 1945. - 1948., Radni materijal - natuknice i kronologija, izradio Šefko Pašić, 1.10., str. 12.

5o Usp. isto, str. 13 . 
je u Slavoniji uhvatila križara Mikruta koji je rodom iz Imotskoga. Isti je agentima UDBA-e odao informacije o kretanju protukomunističke gerile pod vodstvom Bože Mandića..$^{51}$ UDBA je planirala akciju kojom bi $\mathrm{u}$ redove pod vodstvom Bože Mandića ubacila jednu skupinu agenata i oficira KNOJ-a kako bi razotkrila njihove jatake i potom iste likvidirala. Ciljevi su bili omogućiti „bolji politički rad, razbijanje straha među poštenim ljudima toga kraja i stvaranje većeg povjerenja u narodnu

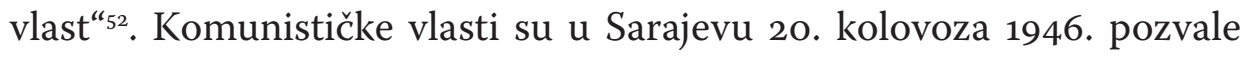
trojicu oficira UDBA-e, devetoricu oficira KNOJ-a i dvojicu radiotelegrafista na Ilidžu. Tu su agenti obučavani za odlazak u akciju likvidiranja protukomunističke gerile. Vođa im je bio Teufik Selimović Buđoni. ${ }^{53}$

Oficiri UDBA-e izradili su plan operacije hvatanja i likvidiranja širokobriješke protukomunističke gerile. Cilj je bio infiltrirati se među mjesno pučanstvo i zatim stupiti u vezu s jatacima kako bi ih oni odveli do čelnih ljudi širokobriješke gerile. Skrili su tu namjeru tako što su se pretvarali da su ih Amerikanci poslali u Hercegovinu s ciljem pripremanja oružanoga ustanka protiv komunističke vlasti. Agenti UDBA-e bili su opremljeni američkim vojnim odijelima i nosili su njihova naoružanja kako bi što bolje zamaskirali namjere. Vodila su ih dvojica bivših pripadnika poraženih oružanih snaga NDH: Franjo koji je u toj grupi glumio poručnika američke vojske i Mikrut, ustaški bojnik. Nadalje, dio ljudstva bio je sastavljen od bivših pripadnika oružanih snaga NDH u kojima je bilo i muslimana. Agenti UDBA-e i KNOJ-a imali su najviše poteškoća oko lomljenja jezika za izgovaranje raznih ustaških pojmova i savladavanja vojne terminologije. Morali su naučiti da je zamjenska riječ za pištolj zapravo samokres, metak je naboj, dežurni je službujući itd. Agenti su se suočavali s poteškoćom savladavanja običaja zapadne Hercegovine, učenja molitve i proučavanja osobnih životopisa križara. Svaki je agent morao dobro savladati i poznavati sve rukovoditelje pojedinih križarskih postrojbi s terena na kojem se nalazio. U izvješću stoji

\footnotetext{
${ }_{51} \quad$ Usp. HR - HDA - 2088 - KGZH 1945. - 1948., Izvješće o likvidaciji grupe Mariofila Mandića i Marka Lončara, 1.9., str. 1.

${ }^{2}$ Isto, str. 1. -2.

53 Usp. BiH - AŽSUBDMŠB - Mandićeva ostavština, sv. 10, mapa 1, podmapa 5., f. 68.
} 
da je bojnik Mikrut s uspjehom izvršavao postavljene zadatke i postupno se oslobađao straha. Isti je, kako se navodi, stekao uvjerenje da će mu se oprostiti sva zlodjela koja je počinio kao ustaša. „Naš odnos prema njemu je neusiljeno oprezan. Nevjerojatno pozna sve rukovoditelje ustaških formacija i mnogo nam pomaže u savladavanju naše legende ${ }^{{ }_{54}}$.

Agenti UDBA-e i KNOJ-a pripremali su se deset dana. Prvo su otišli do Mostara, 2. rujna 1946. krenuli su do Imotskoga, u župu sela Kozice. Kada su stigli, iskrcali su se i krenuli u pravcu sela Mikruti u Imotskome. ${ }^{55}$ Stigli su pred noć 3. rujna. Tu večer nisu dobili nikakve obavještajne informacije o kretanju protukomunističke gerile. Sutradan je skupina agenata UDBA-e i KNOJ-a nastavila putovanje u kotar Ljubuški gdje su sreli Mikrutova prijatelja. Nakon Ljubuškoga 5. rujna stigli su u selo Soviće u kotaru Posušje. ${ }^{56}$ Poslije tri dana boravka u kotaru Posušje preko noći povukli su se kod sela Gradac. Od Zapovjedništva su dobili zadatak da se moraju povući u ilegalu i manje dolaziti u doticaj sa seljacima. ${ }^{57}$

Skupina agenata UDBA-e i KNOJ-a nailazi na probleme zbog nedostatka vode na terenu uslijed velikih vrućina. Sreli su jednoga seljaka u blizini Vranića, na granici posuškoga i širokobriješkoga kotara. Infiltrirali su se među širokobriješke jatake, a jedan od njih, Ilija Mikulić, odveo ih je do Mariofila Mandića. ${ }^{8}$ U izvješću stoji kako se odvio sastanak između Mariofila Mandića i bojnika Mikruta. Tim činom skupina agenata UDBA-e uspješno se infiltrirala u Mandićevu skupinu. ${ }^{59}$ Unatoč tomu, posebno ih je provjeravao Mandićev suborac, bivši zastavnik UNS-a Brale Jurić Bijavica. ${ }^{60}$ Ubrzo su stekli povjerenje Mariofila Mandića i jataka koji su oduševljeno gledali njihov dolazak jer su mislili kako Amerikanci planiraju skoru intervenciju putem zrakoplova i potpomoći ustanak protiv komunističke Jugoslavije. Agenti UDBA-e

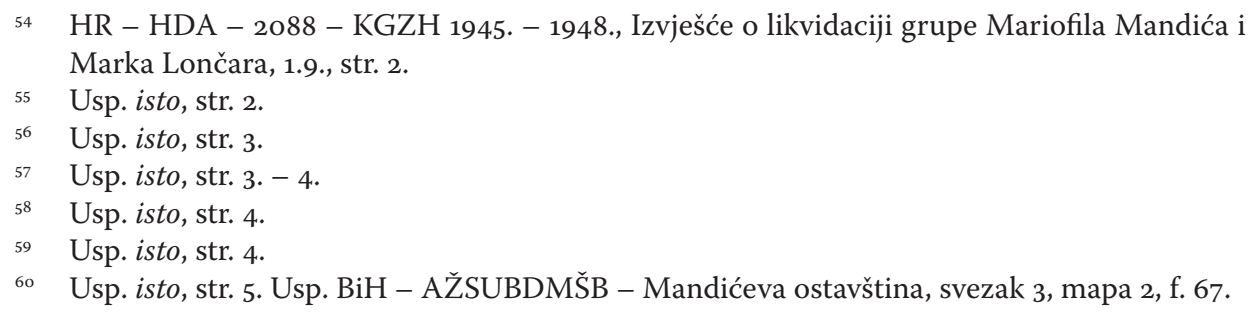


su seljake i protukomunističku gerilu uvjerili u priču oko intervencije američkih zrakoplova koji su trebali pomoći križarima u borbi. Dalje se navodi kako su prema zadatku trebali skupiti sve grupe križara zajedno i pomoću vojske koja prati skupinu agenata OZNA-e i KNOJ-a likvidirati sve agente. „Da bi još više učvrstili njihovo povjerenje dostavljamo im depeše koje dobivamo iz Bari-a u kojima nam se obećava skora zrakoplovna pomoć i naređuje da se bezuvjetno povežemo s rukovodiocem grupa. Mariofil Mandić, pored povjerenja koje je stekao kod nas, i dalje je oprezan i ne daje precizno mjesto skrivanja Bože Mandića"61. Mariofil im navodi kako križari imaju bazu u Čvrsnici u kojoj imaju svoju tehniku, otkuda Božo Mandić rukovodi grupama. Skupina agenata iznijela je plan kretanja preko Ledinca, Turčnovića, Graca, Gostuše, Goranaca i Čabulje prema Čvrsnici. Mariofilova skupina trebala se u blizini Ledinca povezati sa skupinom Benke Penavića. ${ }^{62}$ Prenoćili su u Ledincu i sutradan su u večernjim satima bili nadomak Turčinovića. „Po dolasku u blizinu sela susreli smo dvojicu križara iz skupine Marka Lončara koji su zovnuli Mariofila na razgovor. Isti su ga obavijestili da je jedan odmetnik iz grupe Marka Lončara ubijen, a da je jedan od najvećih zločinaca Vinko Škrobo u neposrednoj blizini ranjen." ${ }^{{ }^{63}}$ Mariofilovi križari sve su više počeli sumnjati u skupinu agenata UDBA-e i KNOJ-a prerušenu u američku vojnu uniformu: „Svjesni smo da u ovoj situaciji ko prvi zapuca taj i pobjeđuje" ${ }^{64}$.

U dosjeu Izvješće o likvidaciji grupe Mariofila Mandića i Marka Lončara sačuvano je samo sedam stranica pisanih na strojopisu, a ostale su uklonjene. Međutim, iz drugih izvora saznajemo kako su se stvari dalje odvijale. Benediktu Benki Penaviću Mikrut je bio sumnjiv i on se s tim nije slagao. Nakon dužih pregovora došlo je do podjele na dvije skupine, na Penavićevu i Mandićevu. Mariofil Mandić je sa svojom satnijom prihvatio agente UDBA-e, dok se Benedikt Benko Penavić odvojio. Skupini pripadnika UDBA-e ciljevi su bili otkriti jatake koji pomažu

${ }_{61}$ HR - HDA - 2088 - KGZH 1945. - 1948., Izvješće o likvidaciji grupe Mariofila Mandića i Marka Lončara, 1.9., str. 6.

62 Usp. isto, str. 6.

${ }_{63}$ Isto, str. 7.

${ }_{64}$ Isto, str. 7. 
protukomunističkoj gerili u hrani i obavijestima te boraviti s njima tri mjeseca i u noći ih ubiti u snu. Benedikt Benko Penavić često je upozoravao Mariofila Mandića da dalje bude oprezan te su se često sastajali, ali Mariofil to nije smatrao bitnim. ${ }^{65} \mathrm{Na}$ brdu Mosoru iznad Širokoga Brijega UDBA je 18. rujna 1946. pobila desetoricu križara: Marijofila Mandića, Zlatka Ćavara, Juru Zovku, Božu Hrkaća, Jakišu Alpezu, Vidaka Prskala, Veselka Rezića, Ivana Jurčića, Ivana Kolobarića i Ivana Katuru ${ }^{66}$ Vođa diverzantske skupine UDBA-e, koja je pobila Mariofilovu skupinu, bio je Teufik Selimović Buđoni. Bila su tri stražara na Mosoru, a od toga dva diverzanta UDBA-e u odorama križara. Obaviještena je postrojba JA u Širokome Brijegu koja se došuljala i opkolila Mariofilovu skupinu. Otvorili su paljbu na njih i pobili ih. Za tu operaciju nisu znale UDBA-e iz Širokoga Brijega i Mostara, nego samo ona iz Sarajeva. ${ }^{67}$ Teufik Selimović kasnije je nastavio živjeti u Beogradu, bez službe u UDBA-i, a zbog iskorištavanja svoga položaja tri je godine proveo u tamnici. $^{68}$

\section{Pokolj ostalih pripadnika širokobriješke protukomunističke gerile od siječnja 1947. do srpnja 1951.}

Agenti UDBA-e 1. siječnja 1947. likvidirali su skupinu pod vodstvom Nike Vladića. ${ }^{69}$ Devet dana nakon toga ubijen je Ivan Kolobarić. Nadalje, agenti UDBA-e su u kaznenoj ekspediciji 25. siječnja ubili Šimuna Šuška, Jozu Musu i Neđu Jakovljevića, a uhitili su Stipu Karačića i Stanka Zeljku..$^{70}$ Prema istraživanjima povjesničara Lučića u Poklečanima je 28. studenoga 1947. ubijen Stanko Zeljko iz Crnča. ${ }^{71}$

\footnotetext{
${ }_{65}$ Usp. BiH - AŽSUBDMŠB - Mandićeva ostavština, sv. 10, mapa 1, podmapa 5., f. 68.

66 Usp. I. LuČIĆ, $n$. dj., str. 651.

${ }_{67}$ Usp. BiH - AŽSUBDMŠB - Mandićeva ostavština, sv. 10, mapa 1, podmapa 5., f. 67.

68 Usp. isto,, f. 68.

69 Usp. HR - HDA - 2088 - KGZH 1945. - 1948., Radni materijal - natuknice i kronologija, izradio Šefko Pašić, 1.10., str. 3.

$7^{7}$ Usp. isto, str. 3.

${ }_{71}$ Usp. I. LuČIĆ, $n$. dj., str. 651.
} 
Izveli su akciju Volarić i Ivan Lasić 27. siječnja 1947. u kojoj je u Pologu uhvaćen Ivan (Jure) Lasić. ${ }^{72}$ U kaznenoj ekspediciji UDBA-e 29. siječnja 1947. likvidirani su Božo Mandić i ostali na Čvrsnici. ${ }^{73}$ Uhvaćeni Ivan Lasić bio je ključan za ubojstvo zapovjednika Bože Mandića. Lasić je u iskazu od 8. svibnja u sjedištu UDBA-e u Mostaru izdao lokaciju zapovjednika Mandića. U završnim riječima optuženi Ivan Lasić je na Okružnome sudu u Mostaru 1948. u predmetu Vinko Pavković i drugi istaknuo kako je uz pripadnike UDBA-e osobno sudjelovao u likvidaciji glavnoga križarskog rukovodstva na čelu s Božom Mandićem i četvoricom njegovih časnika 1947. na planini Čvrsnici. Nadalje navodi kako je pokazao sve križarske baze i veze između križara. Te informacije koristile su agentima UDBA-e za potpunu likvidaciju širokobriješke protukomunističke gerile. „Od moje predaje pa do mog hapšenja osobno sam sudjelovao u likvidaciji križara. Javni tužitelj potvrđuje navedene činjenice i iznosi da su one točne. ${ }^{\text {"74 }}$ Ivan Lasić završio je u tamnici presudom Okružnoga suda u Mostaru u lipnju 1948. i robijao je deset godina u Zenici za nedjela počinjena za vrijeme NDH. ${ }^{75}$

Benedikt Benko Penavić oduzeo si je život 11. prosinca u Bogodolu jer je bio opkoljen agentima UDBA-e, KNOJ-a i JA. Tijelo mu je bilo izloženo u Širokome Brijegu tri dana kao upozorenje narodu da će tako završiti svatko onaj tko se nastavi boriti protiv komunističke vlasti. ${ }^{76}$ UDBA je 23. prosinca 1947. likvidirala Mandu Vrljić te Franu i Juru Vrljića jer su pomagali teško ranjenomu Benediktu Benki Penaviću. ${ }^{77}$

72 Usp. HR - HDA - 2088 - KGZH 1945. - 1948., Radni materijal - natuknice i kronologija, izradio Šefko Pašić, 1.10., str. 4 i 10.

73 Usp. isto, str. 4.

${ }^{74}$ Bosna i Hercegovina (dalje: $\left.\mathrm{BiH}\right)$ - (Pismohrana Vicepostulature postupka mučeništva fra Leo Petrović i 65 subraće (dalje: PVPMLP), MUP NR BiH, Sarajevo, III. odjeljenje broj: 4065/48, Zapisnik od 19. kolovoza 1948. o izvršenoj kazni smrti u predmetu Vinko Pavković i dr., str. 10.

75 Usp. BiH - AŽSUBDMŠB - Mandićeva ostavština, sv. 10, mapa 1, podmapa 5., f. 68. Usp. I. LuČIĆ, $n$. dj., str. 651.

${ }^{6}$ Usp. BiH - AŽSUBDMŠB - Mandićeva ostavština, sv. 10, mapa 1, podmapa 5., f. 68. Usp. I. LUČIĆ, $n$. dj., str. 651.

77 Usp. „Mandu Vrljić iz Goranaca majku četvoro djece i dva njena djevera bez suda strijeljali UDB-aši 1947., Hercegovački info portal, <https://hip.ba/2018/o1/28/ 
Agenti UDBA-e prvi su put teže ranili Vinka Škrobu 1947., a spasila ga je Anica Ćavar Djevojka. ${ }^{78}$ Naposljetku su ga likvidirali 1948. kod Ugrovače, na prostoru Visoke Glavice. Njegovo su tijelo izložili na mostu u Širokome Brijegu. ${ }^{79}$ Godine 1947. uhitili su znatan broj pripadnika Prvoga hercegovačkog križarskog zdruga. Presudom Okružnoga suda u Mostaru 24. svibnja 1948. Vinko Pavković, Božo Karačić, Stanko Ćavar, Milan Bošnjak, Ivan Pavković i Slavko Naletilić osuđeni su na smrtnu kaznu. Pripadnici Narodne milicije strijeljali su optuženike u ponoć 4. kolovoza 1948. kod Južnoga logora, iza vojničkoga groblja u Mostaru. ${ }^{80}$ Isto tako, Okružni sud u Mostaru osudio je pripadnike širokobriješke komunističke gerile, Iliju Ljubića, Tomislava Mandića, Slavka Pavkovića i ostale, na dvadeset godina robije, dok je Ivan Lasić osuđen na deset godina.$^{81}$ Posljednje križarske grupe iz širokobriješke općine likvidirane su 1951. godine. ${ }^{82}$

\section{Zaključak}

Pripadnici protukomunističke gerile, u narodu poznate kao škripari ili križari, bili su pripadnici poraženih oružanih snaga NDH koji su se odbili predati komunističkim vlastima u poraću. Zbog kaznenih ekspedicija tajne policije KPJ sve su teže mogli opstajati u blizini svojih kuća, pa su se skrivali u planinskim područjima Vrana, Ljubuše i Čvrsnice. Komunističke vlasti amnestijom su pozivale sve one koji su se od nje odmetnuli, a nisu počinili zločine na povratku kućama, uz jamstvo da ih neće kazneno goniti. Oko 150 pripadnika širokobriješke protukomunističke gerile odbilo je amnestiju u kolovozu 1945. jer je zapovjednik

mandu-vrljic-iz-goranaca-majku-cetvoro-djece-i-dva-njena-djevera-bez-suda-strijeljaliudb-asi1947-iva-vrljic-s-tek-16-mjeseci-ostala-bez-majke/>, (8. V. 2020.).

${ }_{78}$ Agenti UDB-e su je ubili 27. prosinca 1947. godine.

79 Usp. Ivan Dugandžıć - Josıp Sopta, Rasno - Dužic : Župa Rasno, Matica hrvatska, Široki Brijeg, 1999., str. 148.

8o Usp. BiH - PVPMLP, Okružni sud u Mostaru 1948., Zapisnik o izvršenju smrtne kazne od 4. kolovoza 1948., str. 1.

81 Usp. BiH - PVPMLP, MUP NR BiH, Sarajevo, III. odjeljenje broj: 4065/48, Zapisnik od 19. kolovoza 1948., O izvršenoj kazni smrti u predmetu Vinko Pavković i dr., str. 18-20.

$82 \quad$ Usp. I. LuČić, $n$. $d j$., str. 651. 
Božo Mandić to izričito zabranio. U lipnju 1946. organizirali su se vojno i politički te su utemeljili Prvi hercegovački ustaško-križarski zdrug pod zapovjedništvom ustaškoga satnika Bože Mandića. Navedeni zdrug bio je ustrojen od četiri bojne, a svaka od njih imala je po dvije satnije. Politički cilj križara bio je rušenje komunizma zbog zločina koje su partizani počinili nad Hrvatima pred kraj Drugoga svjetskog rata i nakon njegova završetka. Kako je vrijeme odmicalo, KPJ uvodila je sve nemilosrdnije metode uništenja širokobriješke protukomunističke gerile. Neke od metoda bile su fizičko, ekonomsko i psihičko maltretiranje obitelji pojedinih pripadnika te gerile te prisilna preseljavanja njihovih obitelji. Takve metode izazvale su niz reakcija vodstva Prvoga hercegovačkog ustaško-križarskog zdruga prema Sreskomu komitetu u Širokome Brijegu. Pripadnici širokobriješke protukomunističke gerile samo su na području Širokoga Brijega ubili šest odbornika, 18 vojnika JA i dva oficira KNOJ-a te ranili 12 vojnika JA i tri oficira KNOJ-a. Uz sve navedeno opljačkali su i 35 domaćinstava.

U nekoliko kaznenih ekspedicija UDBA-e ubijena je većina pripadnika širokobriješke protukomunističke gerile. Na brdu Mosoru iznad Širokoga Brijega agenti UDBA-e su pod vodstvom Teufika Selimovića Buđonija 18. rujna 1946. pobili desetoricu križara kojima je na čelu bio Marijofil Mandić. Nekoliko mjeseci poslije toga, točnije 29. siječnja, uz pomoć bivšega gerilca Ivana Lasića agenti UDBA-e ubili su zapovjednika Božu Mandića na Čvrsnici. Benedikt Benko Penavić oduzeo si je život 11. prosinca u Bogodolu jer je bio opkoljen agentima UDBA-e, KNOJ-a i JA. Agenti UDBA-e likvidirali su Vinka Škrobu 1948. kod Ugrovače, na prostoru Visoke Glavice. Također su 1947. uhitili znatan broj pripadnika Prvoga hercegovačkog križarskog zdruga. U sudskome procesu u predmetu Vinko Pavković $i$ ostali na Okružnome sudu u Mostaru šestorica pripadnika širokobriješke protukomunističke gerile osuđena su na smrtnu kaznu strijeljanjem 4. kolovoza 1948., dok su 23 osuđene osobe, među kojima su i jataci iz Širokoga Brijega, dobile kaznu od ukupno 232 godine robijanja u Kazneno-popravnome domu Zenica i u mostarskoj Ćelovini. Presudom su gotovo okončani progoni i pokolji pripadnika 
širokobriješke protukomunističke gerile. Posljednje skupine likvidirane su 1951. na prostoru Širokoga Brijega.

\section{Izvori}

- Bosna i Hercegovina (dalje: BiH), Arhiv hercegovačko-neretvanske županije (dalje: AHNŽ), Sreski komitet saveza komunista Lištica (1945. - 1955.) (dalje: SKSKL), Sreski komitet KPJ Široki Brijeg 1946. - 1947., kut. 18.

- Bosna i Hercegovina (dalje: BiH) - Arhiv župe i samostana Uznesenja Blažene Djevice MarijeŠiroki Brijeg, dalje: (AŽSUBDMŠB) - Mandićeva ostavština.

- Bosna i Hercegovina (dalje: BiH) - (Pismohrana Vicepostulature postupka mučeništva fra Leo Petrović i 65 subraće (dalje: PVPMLP), MUP NR BiH, Sarajevo, III. odjeljenje broj: 4065/48, Zapisnik od 19. kolovoza 1948. o izvršenoj kazni smrti u predmetu "Vinko Pavković i dr.".

- Republika Hrvatska (dalje: HR) - Hrvatski državni arhiv, Zagreb (dalje: HDA) - D2371 - Zbirka mikrofilmova Ministarstvo oružanih snaga 53-b, rola br. 251. (dalje: ZM-MINORS-MF-D-2371, rola br. 251.).

- Republika Hrvatska (dalje: HR) Hrvatski državni arhiv (dalje: HDA) - 2088, Križarske grupe zapadne Hercegovine 1945 - 1948. (dalje: KGZH 1945. - 1948.), Iskaz Ivana Lasića od 1. ožujka 1947. u Odjeljenju UDB-e u Mostaru, 1.2., Iskaz Ivana Pavkovića od 13. ožujka 1948. u Odjeljenju UDB-e u Mostaru, 1.3., Iskaz Slavka Naletilića od 13. ožujka 1948. u Odjeljenju UDB-e u Mostaru, 1.4.,Iskaz Stanka Ćavara od 15. ožujka 1948. u Odjeljenju UDB-e u Mostaru, 1.6., Izvješće o likvidaciji grupe Mariofila Mandića i Marka Lončara, 1.9., Radni materijal - natuknice i kronologija, izradio Šefko Pašić, 1.10., Pismo Mandića i Penavića upućeno 6. svibnja 1946. Marku Šoljiću, 2.2. i Pismo Bože Mandića upućeno 21. svibnja 1946. Marku Šoljiću, 2.3. 


\section{Literatura}

- Dugandžić, Ivan - Sopta, Josip, Rasno - Dužic : Župa Rasno, Matica hrvatska, Široki Brijeg, 1999.

- LuČIĆ, IVICA, „Hrvatska protukomunistička gerila u Bosni i Hercegovini od 1945. do 1951.", Časopis za suvremenu povijest, Zagreb, god. XLII. (2010), br. 3., str.631. - 670.

- Mandić, Hrvoje, „Borbe za Široki Brijeg od početka studenog 1944. do. 7. veljače 1945.", Polemos: časopis za za interdisciplinarna istraživanja rata i mira, Zagreb, god. XVI. (2013.), br. 32., str. 13. -30 .

- MAndić, Hrvoje, „Izbačeni učenici širokobriješke gimnazije od 1941. do 1944. godine“, Zbornik radova s međunarodnoga znanstveno-stručnog skupa u povodu 10o. obljetnice Franjevačke klasične gimnazije s pravom javnosti na Širokom Brijegu, Ivan ŠEvo (gl. ur.), Hercegovačka franjevačka provincija BDM, Široki Brijeg - Mostar, 2019., str. 217. - 234.

- „Mandu Vrljić iz Goranaca majku četvoro djece i dva njena djevera bez suda strijeljali UDB-aši1947., Hercegovački info portal, $<$ https:/hip.ba/2018/o1/28/mandu-vrljic-iz-goranaca-majku-cetvoro-djece-i-dva-njena-djevera-bez-suda-strijeljali-udb-asi1947iva-vrljic-s-tek-16-mjeseci-ostala-bez-majke/>, (8. V. 2020.).

- Matković, BlanKa, „Poslijeratni komunistički zločini i grobišta u istočnoj Hercegovini, Hum, časopis Filozofskog fakulteta Sveučilišta u Mostaru, Mostar, br. 9. (2012), str. 197. - 220.

- ObhoĐaš, Amir - Werhas, Mario -Dimitrijević, Bojan Despot, Zvonimir, Ustaška vojnica 2; Oružana sila Ustaškog pokreta u Nezavisnoj Državi Hrvatskoj 1941.-1945. (druga knjiga, rujan 1943. - svibanj 1945.), Despot Infinitus d.o.o., Zagreb, 2013.

- Radelić, Zdenko, Križari: gerila u Hrvatskoj 1945. - 1950., Dom i svijet, Zagreb, 2011. 
- RAdelić, ZdenKo, „Projugoslavenska protukomunistička gerila u Hrvatskoj nakon Drugog svjetskog rata", Časopis za suvremenu povijest, Zagreb, god. XXXV. (2003.), br. 2., str. 463. - 486. 


\title{
PUNITIVE EXPEDITIONS OF THE COMMUNIST AUTHORITIES AGAINST SIROKI BRIJEG ANTI- COMMUNIST GUERRILLAS 1945-1948
}

\begin{abstract}
Anti-communist guerrillas are armed groups who opposed the newly established Communist regime in the post-war period. Široki Brijeg anti-communist guerrilla was one of the most numerous in West Herzegovina after the Second World War. They were organized militarily and politically in June 1946 and established the First Herzegovinian Ustasha Crusader Association under the command of Ustasha captain Božo Mandić. Political aim of the anti-communist guerrilla was destroying communism because of the crimes done by Partisans over Croats and other nations before the end of the Second World War and after its end. Communist Party of Yugoslavia (KPJ) labeled the mentioned guerrilla as a threat to the process of establishing authority. Using the repressive apparatus KPJ organized numerous punitive expeditions in order to eliminate mentioned guerrillas at the territory of West Herzegovina. Fighting for life in the post-war period, constantly suspected, betrayed and executed by the secret police of KPJ, anti-communist guerrilla committed crimes mostly against national councilors, their families and members of the Young Communist League of Yugoslavia (SKOJ). UDBA agents were not successful in eliminating the anti-communist guerrilla at the beginning. After establishment of Dubrovnik Militia and engaging spies in villages KPJ organized numerous expeditions from 1946 to 1948 in which UDBA agents killed majority of Šroki Brijeg anti-communist guerrilla. Other captured members of the guerrilla were sentenced to death by firing squad or to multiannual imprisonment.
\end{abstract}

Keywords: Siroki Brijeg; anti-communist guerrilla; Božo Mandić; Benedikt Benko Penavić; Vinko Škrobo; UDBA; KNOJ 